\title{
Retraction
}

\section{Retracted: The Design and Implementation of Postprocessing for Depth Map on Real-Time Extraction System}

\author{
The Scientific World Journal \\ Received 27 March 2017; Accepted 27 March 2017; Published 16 July 2017 \\ Copyright (C) 2017 The Scientific World Journal. This is an open access article distributed under the Creative Commons Attribution \\ License, which permits unrestricted use, distribution, and reproduction in any medium, provided the original work is properly \\ cited.
}

The Scientific World Journal has retracted the article titled "The Design and Implementation of Postprocessing for Depth Map on Real-Time Extraction System" [1]. The peer review of the article has been compromised, due to a conflict of interest between the handling editor and one of the authors.

\section{References}

[1] Z. Tang, B. Li, H. Li, and Z. Xu, “The design and implementation of postprocessing for depth map on real-time extraction System," The Scientific World Journal, vol. 2014, Article ID 363287, 10 pages, 2014. 